JURNAL GIZI DAN DIETETIK INDONESIA

Vol. 2, No. 3, September 2014: 103-115

\title{
Ketahanan pangan rumah tangga berhubungan dengan stunting pada anak usia 6-23 bulan
}

Household food security correlated with stunting in children 6-23 months

Masrin', Yhona Paratmanitya², Veriani Aprilia $^{3}$

\begin{abstract}
Background: Food is one of human basic needs. If it is not fullfilled, both in their number and quality in the individual and household level will disturb the achievement of the life quality that are health, active, and sustainable and able to rise various health and nutrition problems. Stunting in children 6-23 months was one of chronical nutrition problems that was caused by access and afford to the food still low. Objectives: To analyze the correlation between food security of the household and stunting incidence in children aged 6-23 months in Sedayu Subdistrict, Bantul, Yogyakarta.

Methods: This was an observational study with case-control design. The samples of the study were 126 children aged 6-23 months, each for case, and control group. The samples were chosen by total sampling method. Data were analyzed by using univariate, bivariate, and multivariate. Statistic test in bivariate analysis used chi-square test and in multivariate analysis used logistic regression test.

Results: Bivariate analysis showed that food security of the household had correlation with stunting incidence in children aged 6-23 months ( $p=0.04$, OR=2.70, 95\% Cl:0.94-8.77). The confounding variable which had significant correlation with stunting incidence in children aged 6-23 months were mother height $(p=0.00, O R=2.03,95 \% \mathrm{Cl}: 1.14-3.65)$ and low birth weigth history $(p=0.03, \mathrm{OR}=3.02,95 \% \mathrm{Cl}: 0.98-11.04)$. Multivariate analysis by controlling mother height and low birth weigth history in children aged 6-23 months, showed that household food security had correlation with stunting incidence in children aged their 6-23 months ( $p=0.05$, OR=2.62, 95\% Cl:0.97-7.12).

Conclusions: There was significant correlation between household food security and stunting incidence in children aged at their 6-23 months in Sedayu Subdistrict, Bantul, Yogyakarta.
\end{abstract}

KEYWORDS: household food security, stunting, children aged in 6-23 months

\begin{abstract}
ABSTRAK
Latar belakang: Pangan merupakan salah satu kebutuhan dasar manusia. Jika kebutuhan tersebut tidak terpenuhi, baik jumlah maupun mutunya pada tingkat individu dan rumah tangga akan mengganggu tercapainya kualitas hidup sehat, aktif, dan berkesinambungan serta dapat menimbulkan berbagai permasalahan kesehatan dan gizi. Baduta stunting merupakan salah satu masalah gizi kronis yang disebabkan oleh akses dan keterjangkauan terhadap pangan masih rendah.

Tujuan: Menganalisis hubungan ketahanan pangan rumah tangga dengan kejadian stunting pada balita usia 6-23 bulan di Kecamatan Sedayu, Bantul, Yogyakarta.

Metode: Jenis penelitian ini adalah observasional dengan rancangan case-control. Sampel penelitian adalah baduta usia 6-23 bulan yang berjumlah 126 untuk masing-masing kelompok kasus dan kontrol dengan rasio 1:1. Teknik pengambilan sampel menggunakan metode total sampling. Analisis data secara bertahap, yaitu analisis univariat, bivariat, dan multivariat. Uji statistik bivariat menggunakan chi-square dan multivariat menggunakan regresi logistik.
\end{abstract}

\footnotetext{
${ }^{1}$ STIK Avicenna, JI. D.I Panjaitan Lepo-Lepo, Kendari-Sulawesi Tenggara, e-mail: masrinupiqaqib@gmail.com

2 Program Studi S1 IImu Gizi, STIKES Alma Ata Yogyakarta, Jl. Ring Road Barat Daya No 1, Yogyakarta 55183, e-mail: yhona_nitya@ yahoo.com

3 Program Studi S1 IImu Gizi, STIKES Alma Ata Yogyakarta, Jl. Ring Road Barat Daya No 1, Yogyakarta 55183, e-mail: aprilia.triwanto@ gmail.com
} 
Hasil: Hasil analisis bivariat menunjukkan ketahanan pangan rumah tangga berhubungan dengan kejadian stunting pada baduta usia 6-23 bulan ( $p=0,04, \mathrm{OR}=2,70,95 \% \mathrm{Cl}: 0,94-8,77)$. Variabel luar yang berhubungan signifikan dengan kejadian stunting pada baduta usia 6-23 bulan yaitu tinggi badan ibu $(p=0,00, O R=2,03,95 \% \mathrm{Cl}: 1,14-3,65)$ dan riwayat $B B L R(p=0,03, O R=3,02,95 \% \mathrm{Cl}: 0,98-11,04)$. Hasil analisis multivariat dengan mengendalikan variabel tinggi badan ibu dan riwayat BBLR baduta menunjukkan ketahanan pangan rumah tangga berhubungan dengan kejadian stunting pada baduta usia 6-23 bulan ( $p=0,05$, OR=2,62, 95\% Cl:0,97-7,12).

Kesimpulan: Ada hubungan yang signifikan antara ketahanan pangan rumah tangga dengan kejadian stunting pada baduta usia 6-23 bulan di Kecamatan Sedayu, Bantul, Yogyakarta.

KATA KUNCI: ketahanan pangan rumah tangga, stunting, baduta usia 6-23 bulan

\section{PENDAHULUAN}

Pembangunan ketahanan pangan diselenggarakan untuk memenuhi kebutuhan dasar manusia yang memberikan manfaat secara adil dan merata berdasarkan kemandirian dan tidak bertentangan dengan keyakinan masyarakat, sehingga terbentuk manusia Indonesia yang berkualitas, mandiri, dan sejahtera melalui perwujudan ketersediaan pangan yang cukup, aman, bermutu, bergizi, dan beragam serta tersebar merata di seluruh wilayah Indonesia dan terjangkau oleh masyarakat $(1,2)$. Munculnya berbagai permasalahan kurang gizi disebabkan oleh tidak tercapainya ketahanan gizi sebagai dampak dari ketahanan pangan rumah tangga yang tidak terpenuhi (3).

Berbagai faktor yang mempengaruhi ketahanan pangan seperti pendapatan keluarga, pendidikan, dan kepemilikan aset produktif secara bersama-sama berpengaruh terhadap kerawanan pangan (4). Jumlah anggota keluarga, tingkat pendidikan, harga bahan makanan, dan pendapatan keluarga secara bersamasama juga berpengaruh terhadap ketahanan pangan rumah tangga (5).

Prevalensi balita stunting di Indonesia menurut data riset kesehatan dasar (Riskesdas) tahun 2010 yaitu sebesar $35,5 \%$ dan $18,5 \%$ untuk balita dengan tinggi badan sangat pendek, sedangkan di Daerah Istimewa Yogyakarta (DIY) diperoleh data sebesar $22,5 \%$ balita menderita stunting dan $10,2 \%$ menderita sangat pendek (6). Prevalensi stunting pada balita di Kabupaten Bantul adalah $18,08 \%(7)$.

Karakteristik kabupaten/kota dengan prevalensi stunting yang cukup tinggi adalah pendapatan per kapita penduduknya rendah, tingkat pendidikan rendah, dan perilaku higiene yang tidak baik (8). Senada dengan hal ini, terdapat hubungan yang signifikan antara ketahanan pangan tingkat rumah tangga berdasarkan konsumsi energi dengan status gizi balita maupun batita, yakni semakin tinggi skor rata-rata nilai ketahanan pangan, semakin baik status gizinya $(9,10)$. Penelitian ini bertujuan untuk menganalisis hubungan antara ketahanan pangan dengan kejadian stunting pada baduta usia 6-23 bulan di Kecamatan Sedayu, Bantul, Yogyakarta.

\section{BAHAN DAN METODE}

Jenis penelitian ini adalah observasional dengan rancangan case-control. Kasus adalah ibu rumah tangga yang memiliki balita stunting usia 6-23 bulan, sedangkan kontrol adalah ibu rumah tangga yang tidak memiliki balita stunting usia 6-23 serta berasal dari populasi yang sama dengan kasus. Penelitian ini merupakan bagian dari penelitian yang berjudul "Status Gizi lbu Hamil dan Baduta di Kecamatan Sedayu Kabupaten Bantul D.I Yogyakarta" yang dilaksanakan oleh Alma Ata Center For Healthy Life and Food (ACHEAF) Yogyakarta.

Penelitian dilaksanakan di Kecamatan Sedayu, Bantul, Yogyakarta pada periode bulan Maret sampai Mei 2014. Populasi penelitian adalah ibu rumah tangga beserta anaknya yang berusia 6-23 bulan dan tinggal di Kecamatan Sedayu Kabupaten Bantul DIY. Sampel dipilih dengan menggunakan metode total sampling.

Besar sampel minimal diperoleh dengan menggunakan rumus uji hipotesis perbedaan 2 proporsi (11) dan jumlah sampel yang diperoleh adalah 123 baduta. Total baduta yang menderita 
stunting setelah dilakukan skrining dan seleksi sesuai kriteria inklusi dan eksklusi sebanyak 126 baduta. Setelah mempertimbangkan jumlah sampel minimal yang selisihnya sedikit dibanding total sampel, akhirnya semua baduta dipilih menjadi sampel penelitian (total sampling) dengan perbandingan kasus dan kontrol 1:1. Dengan demikian, total sampel kasus kontrol berjumlah 252 baduta.

Kriteria inklusi kasus yaitu: ibu rumah tangga beserta anaknya yang berusia 6-23 bulan dan telah tinggal di Kecamatan Sedayu, Bantul, Yogyakarta minimal 6 bulan, baduta usia 6-23 bulan yang menderita stunting, tercatat di posyandu wilayah Kecamatan Sedayu, ibu bersedia menjadi responden, dan mengizinkan anaknya menjadi sampel penelitian selama penelitian berlangsung dengan menandatangani lembar pernyataan kesediaan menjadi responden (informed consent). Kriteria inklusi kontrol yaitu: ibu rumah tangga beserta anaknya yang berusia 6-23 bulan dan telah tinggal di Kecamatan Sedayu Bantul, Yogyakarta minimal 6 bulan, baduta usia 6-23 bulan yang memiliki panjang badan normal, tercatat di posyandu wilayah Kecamatan Sedayu, ibu bersedia menjadi responden, dan mengizinkan anaknya menjadi sampel penelitian selama penelitian berlangsung dengan menandatangani lembar pernyataan kesediaan menjadi responden (informed consent). Kriteria eksklusi kasus dan kontrol adalah baduta tersebut bukan sebagai anak kandung, orang tua berada di luar wilayah lokasi penelitian dan tidak memungkinkan penulis bertemu untuk melakukan pengukuran tinggi badan, salah satu atau kedua orang tua telah meninggal, baduta sedang dirawat di rumah sakit. Kontrol dipilih dari 1 populasi rukun warga dan bertempat tinggal dalam satu wilayah posyandu yang sama dengan kasus dan matching dilakukan pada umur.

Variabel bebas penelitian ini adalah ketahanan pangan rumah tangga dan variabel terikatnya adalah baduta stunting dengan usia 6-23 bulan. Variabel counfounding yaitu: pendidikan ayah, pendidikan ibu, pekerjaan ayah, pekerjaan ibu, pendapatan keluarga, dan jumlah anggota keluarga. Variabel antara terdiri dari riwayat asupan energi dan riwayat asupan protein. Variabel luar terdiri dari: tinggi badan ayah, tinggi badan ibu, pengetahuan gizi ibu, jenis kelamin baduta, riwayat BBLR, dan penyakit infeksi.

Data penelitian diperoleh melalui wawancara dan pengukuran langsung, selanjutnya diinput ke dalam program Commcare ODK handphone Android dan diolah secara komputerisasi. Data ketahanan pangan rumah tangga diperoleh dengan menggunakan instrumen yang dikembangkan oleh Radimer et al (12). Data stunting baduta diperoleh melalui pengukuran langsung menggunakan infantometer, data riwayat asupan energi diperoleh melalui wawancara menggunakan form semiquantitative food frequency questionnaire (SQFFQ), data tinggi badan orang tua diperoleh dengan pengukuran langsung menggunakan microtoise, sedangkan data pendidikan orang tua, pekerjaan orang tua, pendapatan keluarga, jumlah anggota keluarga, pengetahuan gizi ibu, jenis kelamin, riwayat BBLR (berat badan lahir rendah, dan penyakit infeksi diperoleh melalui wawancara menggunakan kuesioner. Analisis data bivariat menggunakan chi-square dan analisis multivariat menggunakan regresi logistik.

Uji validitas dan reliabilitas kuesioner dilakukan terhadap 30 ibu baduta. Kuesioner yang diujicobakan adalah kuesioner penilaian ketahanan pangan dan pengetahuan gizi ibu. Butir pertanyaan dinyatakan valid apabila nilai corrected item-total correlation $>0,361$ dan dinyatakan reliabel apabila nilai cronbach's alpha >0,361 (13). Hasil menunjukkan kuesioner valid dan reliabel karena nilai cronbach's alpha $>0,361$. Penelitian ini sudah memperoleh surat kelayakan etik (ethical clearance) dari Komisi Etik Penelitian Kedokteran dan Kesehatan Fakultas Kedokteran Universitas Gadjah Mada Yogyakarta dengan nomor Ref: KE/F/382/EC tahun 2014.

\section{HASIL}

\section{Karakteristik subjek penelitian}

Karakteristik subjek penelitian ini dapat dilihat pada Tabel 1. Berdasarkan data pada Tabel 1 diketahui bahwa riwayat BBLR dan tinggi badan ibu secara signifikan berbeda antara kelompok kasus 
Tabel 1. Distribusi frekuensi karakteristik responden berdasarkan sosial ekonomi dan status gizi keluarga

\begin{tabular}{|c|c|c|c|c|c|}
\hline \multirow[t]{2}{*}{ Variabel } & \multicolumn{2}{|c|}{$\begin{array}{c}\text { Kasus } \\
(n=126)\end{array}$} & \multicolumn{2}{|c|}{$\begin{array}{l}\text { Kontrol } \\
(n=126)\end{array}$} & \multirow[t]{2}{*}{$\mathbf{p}$} \\
\hline & $\mathbf{n}$ & $\%$ & $\mathbf{n}$ & $\%$ & \\
\hline \multicolumn{6}{|c|}{ Riwayat asupan energi } \\
\hline Kurang & 15 & 50,00 & 15 & 50,00 & 1,00 \\
\hline Baik & 111 & 50,00 & 111 & 50,00 & \\
\hline \multicolumn{6}{|c|}{ Riwayat asupan protein } \\
\hline Kurang & 11 & 52,38 & 10 & 47,62 & 0,82 \\
\hline Baik & 115 & 49,78 & 116 & 50,22 & \\
\hline \multicolumn{6}{|l|}{ Pendidikan ayah } \\
\hline Kurang & 43 & 48,31 & 46 & 51,69 & 0,69 \\
\hline Baik & 83 & 50,92 & 80 & 49,08 & \\
\hline \multicolumn{6}{|l|}{ Pendidikan ibu } \\
\hline Kurang & 42 & 47,73 & 46 & 52,27 & 0,59 \\
\hline Baik & 84 & 51,22 & 80 & 48,78 & \\
\hline \multicolumn{6}{|l|}{ Pekerjaan ayah } \\
\hline Kurang & 86 & 53,42 & 75 & 46,58 & 0,15 \\
\hline Baik & 40 & 43,96 & 51 & 56,04 & \\
\hline \multicolumn{6}{|l|}{ Pekerjaan ibu } \\
\hline Kurang & 106 & 51,21 & 101 & 48,79 & 0,41 \\
\hline Baik & 20 & 44,44 & 25 & 55,56 & \\
\hline \multicolumn{6}{|l|}{ Tinggi badan ayah } \\
\hline Pendek & 46 & 54,76 & 38 & 45,24 & 0,28 \\
\hline Normal & 80 & 47,62 & 88 & 52,38 & \\
\hline \multicolumn{6}{|l|}{ Tinggi badan ibu } \\
\hline Pendek & 49 & 62,03 & 30 & 37,97 & $0,01^{*}$ \\
\hline Normal & 77 & 44,51 & 96 & 55,49 & \\
\hline \multicolumn{6}{|l|}{ Pendapatan keluarga } \\
\hline Kurang & 81 & 48,21 & 87 & 51,79 & 0,42 \\
\hline Baik & 45 & 53,57 & 39 & 46,43 & \\
\hline \multicolumn{6}{|c|}{ Jumlah anggota keluarga } \\
\hline Kurang & 71 & 51,82 & 66 & 48,18 & 0,53 \\
\hline Baik & 55 & 47,83 & 60 & 52,17 & \\
\hline \multicolumn{6}{|l|}{ Pengetahuan gizi ibu } \\
\hline Kurang & 70 & 54,26 & 59 & 45,74 & 0,16 \\
\hline Baik & 56 & 45,53 & 67 & 54,47 & \\
\hline \multicolumn{6}{|l|}{ Jenis kelamin } \\
\hline Laki-laki & 66 & 47,14 & 74 & 52,86 & 0,31 \\
\hline Perempuan & 60 & 53,57 & 52 & 46,43 & \\
\hline \multicolumn{6}{|l|}{ Riwayat BBLR } \\
\hline BBLR & 14 & 73,68 & 5 & 26,32 & $0,03^{*}$ \\
\hline Normal & 112 & 48,07 & 121 & 51,93 & \\
\hline \multicolumn{6}{|l|}{ Penyakit infeksi } \\
\hline Ada infeksi & 78 & 50,98 & 75 & 49,02 & 0,69 \\
\hline Tidak ada infeksi & 48 & 48,48 & 51 & 51,52 & \\
\hline
\end{tabular}

* Signifikan $(p<0,05)$ dan kelompok kontrol, sementara karakteristik subjek penelitian yang lain tidak berbeda signifikan. Hal ini menunjukkan bahwa kelompok kasus dan kontrol mempunyai distribusi yang setara dalam karakteristik tersebut.

\section{Analisis bivariat}

Analisis ini dilakukan untuk menguji hubungan antara variabel bebas, variabel counfounding dan variabel luar dengan variabel bebas. Uji statistik yang digunakan adalah chi-square $\left(\chi^{2}\right)$ dengan $\mathrm{p}=0,05$ dan confidence interval $(\mathrm{Cl}) 95 \%$.

Berdasarkan Tabel 2, terlihat bahwa terdapat hubungan antara ketahanan pangan rumah tangga dengan kejadian stunting pada baduta usia 6-23 bulan di Kecamatan Sedayu, Bantul, Yogyakarta $(p=0,04,95 \%$ Cl:1,04-7,00). Hal ini menunjukkan bahwa ketahanan pangan rumah tangga merupakan faktor risiko yang signifikan terhadap kejadian stunting pada baduta usia 6-23 bulan di Kecamatan Sedayu, Bantul, Yogyakarta dengan nilai $\mathrm{OR}=2,70$, artinya rumah tangga yang berada pada kondisi rawan pangan berisiko 2,70 kali lebih besar memiliki baduta stunting dibandingkan dengan rumah tangga yang berada pada kondisi tahan pangan.

Menurut Tabel 3, terlihat bahwa persentase kejadian stunting lebih tinggi pada kelompok dengan tinggi badan ibu pendek $(62,03 \%)$ dibandingkan dengan kelompok yang tinggi badan ibunya normal $(44,51 \%)$. Hasil analisis bivariat menunjukkan bahwa tinggi badan ibu merupakan faktor risiko yang signifikan terhadap kejadian stunting $(p=0,00,95 \%$ $\mathrm{Cl}: 1,14-3,65)$. Perhitungan nilai OR diperoleh 2,03 artinya ibu dengan tinggi badan pendek, berisiko 2,03 kali lebih besar memiliki baduta stunting dibandingkan dengan ibu yang memiliki tinggi badan normal. Berdasarkan data ini pula diketahui bahwa pengaruh genetik mendukung terjadinya stunting pada baduta usia 6-23 bulan.

Data dari tabel tersebut menunjukkan bahwa kejadian BBLR pada kelompok kasus sebanyak $73,68 \%$ lebih tinggi dari kelompok kontrol $26,32 \%$. Hasil analisis bivariat menunjukkan riwayat BBLR 
Tabel 2. Analisis bivariat hubungan variabel bebas, variabel antara dan variabel confounding dengan kejadian stunting pada baduta usia 6-23 bulan di Kecamatan Sedayu, Bantul, Yogyakarta tahun 2014

\begin{tabular}{|c|c|c|c|c|c|c|c|c|}
\hline \multirow{2}{*}{ Variabel } & \multicolumn{2}{|c|}{ Kasus } & \multicolumn{2}{|c|}{ Kontrol } & \multicolumn{2}{|c|}{ Total } & \multirow{2}{*}{$\begin{array}{c}\text { OR } \\
(95 \% \mathrm{Cl}) \\
\end{array}$} & \multirow{2}{*}{$\mathbf{p}$} \\
\hline & $\mathbf{n}$ & $\%$ & $\mathbf{n}$ & $\%$ & $\mathbf{n}$ & $\%$ & & \\
\hline \multicolumn{9}{|l|}{ Variabel bebas } \\
\hline \multicolumn{9}{|c|}{ Ketahanan pangan rumah tangga } \\
\hline Rawan pangan & 15 & 71,43 & 6 & 28,57 & 21 & 100 & 2,70 & $0,04^{*}$ \\
\hline Tahan pangan & 111 & 48,05 & 120 & 51,95 & 231 & 100 & $(1,04-7,00)$ & \\
\hline \multicolumn{9}{|l|}{ Variabel antara } \\
\hline \multicolumn{9}{|c|}{ Riwayat asupan energi } \\
\hline Kurang & 15 & 50,00 & 15 & 50,00 & 30 & 100 & 1,00 & 1,00 \\
\hline Baik & 111 & 50,00 & 111 & 50,00 & 222 & 100 & $(0,43-2,31)$ & \\
\hline \multicolumn{9}{|c|}{ Riwayat asupan protein } \\
\hline Kurang & 11 & 52,38 & 10 & 47,62 & 21 & 100 & 1,10 & 0,82 \\
\hline Baik & 115 & 49,78 & 116 & 50,22 & 231 & 100 & $(0,40-3,03)$ & \\
\hline \multicolumn{9}{|l|}{ Variabel counfounding } \\
\hline \multicolumn{9}{|l|}{ Pendidikan ayah } \\
\hline Kurang & 43 & 48,31 & 46 & 51,69 & 89 & 100 & 0,90 & 0,69 \\
\hline Baik & 83 & 50,92 & 80 & 49,08 & 163 & 100 & $(0,51-1,56)$ & \\
\hline \multicolumn{9}{|l|}{ Pendidikan ibu } \\
\hline Kurang & 42 & 47,73 & 46 & 52,27 & 88 & 100 & 0,86 & 0,59 \\
\hline Baik & 84 & 51,22 & 80 & 48,78 & 164 & 100 & $(0,50-1,50)$ & \\
\hline \multicolumn{9}{|l|}{ Pekerjaan ayah } \\
\hline Kurang & 86 & 53,42 & 75 & 46,58 & 161 & 100 & 1,46 & 0,15 \\
\hline Baik & 40 & 43,96 & 51 & 56,04 & 91 & 100 & $(0,84-2,54)$ & \\
\hline \multicolumn{9}{|l|}{ Pekerjaan ibu } \\
\hline Kurang & 106 & 51,21 & 101 & 48,79 & 207 & 100 & 1,31 & 0,41 \\
\hline Baik & 20 & 44,44 & 25 & 55,56 & 45 & 100 & $(0,65-2,65)$ & \\
\hline \multicolumn{9}{|l|}{ Pendapatan keluarga } \\
\hline Kurang & 81 & 48,21 & 87 & 51,79 & 168 & 100 & 0,80 & 0,42 \\
\hline Baik & 45 & 53,57 & 39 & 46,43 & 84 & 100 & $(0,46-1,41)$ & \\
\hline \multicolumn{9}{|c|}{ Jumlah anggota keluarga } \\
\hline Kurang & 81 & 48,21 & 87 & 51,79 & 168 & 100 & 0,80 & 0,42 \\
\hline Baik & 45 & 53,57 & 39 & 46,43 & 84 & 100 & $(0,46-1,41)$ & \\
\hline
\end{tabular}

* Signifikan $(p<0,05)$

merupakan faktor risiko yang signifikan terhadap kejadian stunting pada baduta usia 6-23 bulan $(p=0,03,95 \% \mathrm{Cl}: 1,09-8,32)$. Berdasarkan hasil analisis diperoleh nilai $\mathrm{OR}=3,02$ artinya baduta yang terlahir dengan berat badan lahir rendah, berisiko 3,02 kali lebih besar menderita stunting dibandingkan dengan baduta yang memiliki berat badan normal.

Analisis data pada Tabel 4 menunjukkan bahwa $66,67 \%$ baduta pada kelompok kasus yang berasal dari rumah tangga rawan pangan memiliki asupan energi kategori baik. Demikian pula pada Tabel 5 menunjukkan bahwa 73,33\% baduta pada kelompok kasus yang berasal dari rumah tangga rawan pangan memiliki asupan protein kategori baik.
Analisis bivariat menunjukkan tidak ada hubungan antara ketahanan pangan rumah tangga dengan asupan energi dan protein pada baduta.

\section{Analisis multivariat}

Analisis multivariat dilakukan untuk mengetahui hubungan ketahanan pangan rumah tangga dengan kejadian stunting, dengan mengendalikan variabel luar yang memiliki nilai $p<0,05$ pada uji bivariat. Uji hipotesis yang digunakan adalah uji regresi logistik dengan tingkat kemaknaan $\mathrm{p}=0,05$ dan $95 \% \mathrm{Cl}$. Nilai -2 log likelihood digunakan untuk membandingkan perbedaan model yang satu dengan lainnya. Coefisien determinan atau $\left(\mathrm{R}^{2}\right)$ untuk melihat 
Tabel 3. Analisis bivariat hubungan variabel luar dengan kejadian stunting pada baduta usia 6-23 bulan dan di Kecamatan Sedayu, Bantul, Yogyakarta tahun 2014

\begin{tabular}{|c|c|c|c|c|c|c|c|c|}
\hline \multirow{2}{*}{ Variabel } & \multicolumn{2}{|c|}{ Kasus } & \multicolumn{2}{|c|}{ Kontrol } & \multicolumn{2}{|c|}{ Total } & \multirow{2}{*}{$\begin{array}{c}\text { OR } \\
(95 \% \mathrm{Cl})\end{array}$} & \multirow{2}{*}{$\mathbf{p}$} \\
\hline & $\mathbf{n}$ & $\%$ & $\mathbf{n}$ & $\%$ & $\mathbf{n}$ & $\%$ & & \\
\hline \multicolumn{9}{|l|}{ Pengetahuan gizi ibu } \\
\hline Kurang & 70 & 54,26 & 59 & 45,74 & 129 & 100 & 1,41 & 0,16 \\
\hline Baik & 56 & 45,53 & 67 & 54,47 & 123 & 100 & $(0,83-2,40)$ & \\
\hline \multicolumn{9}{|l|}{ Tinggi badan ayah } \\
\hline Pendek & 46 & 54,76 & 38 & 45,24 & 84 & 100 & 1,33 & 0,28 \\
\hline Normal & 80 & 47,62 & 88 & 52,38 & 168 & 100 & $(0,76-2,33)$ & \\
\hline \multicolumn{9}{|l|}{ Tinggi badan ibu } \\
\hline Pendek & 49 & 62,03 & 30 & 37,97 & 79 & 100 & 2,03 & $0,00^{*}$ \\
\hline Normal & 77 & 44,51 & 96 & 55,49 & 173 & 100 & $(1,14-3,65)$ & \\
\hline \multicolumn{9}{|l|}{ Jenis kelamin } \\
\hline Laki-laki & 66 & 47,14 & 74 & 52,86 & 140 & 100 & 0,77 & 0,31 \\
\hline Perempuan & 60 & 53,57 & 52 & 46,43 & 112 & 100 & $(0,45-1,31)$ & \\
\hline \multicolumn{9}{|l|}{ Riwayat BBLR } \\
\hline BBLR & 14 & 73,68 & 5 & 26,32 & 19 & 100 & 3,02 & $0,03^{*}$ \\
\hline BBLN & 112 & 48,07 & 121 & 51,93 & 233 & 100 & $(1,09-8,32)$ & \\
\hline \multicolumn{9}{|l|}{ Penyakit infeksi } \\
\hline Ada infeksi & 78 & 50,98 & 75 & 49,02 & 153 & 100 & 1,10 & 0,69 \\
\hline Tidak ada infeksi & 48 & 48,48 & 51 & 51,52 & 99 & 100 & $(0,64-1,89)$ & \\
\hline
\end{tabular}

* Signifikan $(p<0,05)$

Tabel 4. Analisis bivariat hubungan ketahanan pangan rumah tangga dengan asupan energi pada baduta usia 6-23 bulan di Kecamatan Sedayu, Bantul, Yogyakarta tahun 2014

\begin{tabular}{ccccc}
\hline \multirow{2}{*}{ Ketahanan pangan rumah tangga } & \multicolumn{2}{c}{ Asupan energi } & \multirow{2}{*}{ Total } & \multirow{2}{*}{$\mathbf{p}$} \\
\cline { 2 - 3 } & Kurang & Baik & & \\
\hline Rawan pangan & $5(23,81 \%)$ & $16(76,19 \%)$ & $21(100 \%)$ & \multirow{2}{*}{0,078} \\
Tahan pangan & $25(10,82 \%)$ & $206(89,18 \%)$ & $231(100 \%)$ & \\
\hline
\end{tabular}

Tabel 5. Analisis bivariat hubungan ketahanan pangan rumah tangga dengan asupan protein pada baduta usia 6-23 bulan di Kecamatan Sedayu, Bantul, Yogyakarta tahun 2014

\begin{tabular}{ccccc}
\hline \multirow{2}{*}{ Ketahanan pangan rumah tangga } & \multicolumn{2}{c}{ Asupan protein } & \multirow{2}{*}{ Total } & \multirow{2}{*}{ p } \\
\cline { 2 - 3 } & Kurang & Baik & & \\
\hline Rawan pangan & $4(19,05 \%)$ & $17(80,95 \%)$ & $21(100 \%)$ & \multirow{2}{*}{0,064} \\
Tahan pangan & $17(7,36 \%)$ & $214(92,64 \%)$ & $231(100 \%)$ & \\
\hline
\end{tabular}

* Signifikan $(p<0,05)$

kemampuan seluruh variabel dalam setiap model memprediksi terjadinya stunting.

Analisis model 1 untuk mengetahui adanya hubungan ketahanan pangan rumah tangga dengan kejadian stunting pada baduta usia 6-23 bulan tanpa melibatkan variabel lain. Hasil analisis menunjukkan ada hubungan yang signifikan antara ketahanan pangan rumah tangga dengan kejadian stunting (OR=2,70, 95\% Cl:1,01-7,21). Berdasarkan analisis model 1 dapat dijelaskan bahwa baduta usia 6-23 bulan yang berada pada rumah tangga rawan pangan memiliki risiko 2,7 kali lebih besar menderita stunting dibandingkan dengan baduta yang berada pada rumah tangga tahan pangan. Nilai $R^{2}(\%)=0,01$ sehingga dapat diartikan bahwa ketahanan pangan rumah tangga dapat memprediksi kejadian stunting pada baduta usia $6-23$ bulan sebesar $1 \%$ sedangkan 99\% disebabkan oleh faktor lain.

Analisis model 2 untuk mengetahui adanya hubungan ketahanan pangan rumah tangga dengan 
kejadian stunting pada baduta usia 6-23 bulan dengan mengikutsertakan variabel tinggi badan ibu dalam analisis. Hasil analisis menunjukkan bahwa baduta yang memiliki ibu dengan tinggi badan normal $(>150 \mathrm{~cm})$ dapat menurunkan faktor risiko kejadian stunting sebesar 0,7 kali (OR=2,63, 95\% Cl:0,97$7,09)$. Hal ini berarti bahwa baduta pada rumah tangga rawan pangan memiliki risiko menderita stunting 2,63 kali lebih besar dibandingkan dengan baduta pada rumah tangga tahan pangan apabila baduta memiliki tinggi badan ibu normal $(>150 \mathrm{~cm})$. Nilai $R^{2}(\%)=0,03$, sehingga dapat diartikan secara bersama-sama ketahanan pangan rumah tangga dan tinggi badan ibu dapat memprediksi kejadian stunting pada baduta usia 6-23 bulan sebesar 3\% sedangkan $97 \%$ disebabkan oleh faktor lain.

Analisis model 3 untuk mengetahui adanya hubungan ketahanan pangan rumah tangga dengan kejadian stunting pada baduta usia 6-23 bulan dengan mengikutsertakan variabel riwayat BBLR baduta. Hasil analisis menunjukkan bahwa baduta yang memiliki riwayat berat badan lahir normal (berat badan lahir $\geq 2.500$ gram) dapat menurunkan faktor risiko kejadian stunting sebesar 0,1 kali (OR=2,69, 95\% Cl:1,00-7,22). Hal ini berarti bahwa baduta pada rumah tangga rawan pangan memiliki risiko menderita stunting 2,69 kali lebih besar dibandingkan dengan baduta pada rumah tangga tahan pangan apabila baduta memiliki riwayat berat badan lahir normal. Nilai $\mathrm{R}^{2}(\%)=0,02$ sehingga dapat diartikan secara bersama-sama ketahanan pangan rumah tangga dan riwayat berat badan lahir rendah dapat memprediksi kejadian stunting pada baduta usia $6-23$ bulan sebesar $2 \%$ sedangkan $98 \%$ disebabkan oleh faktor lain.

Analisis model 4 untuk mengetahui adanya hubungan ketahanan pangan rumah tangga dengan kejadian stunting pada baduta usia 6-23 bulan dengan mengikutsertakan variabel tinggi badan ibu dan riwayat BBLR baduta. Hasil analisis menunjukkan bahwa baduta yang memiliki ibu dengan tinggi badan normal $(T B>150 \mathrm{~cm})$ dan memiliki riwayat berat badan lahir normal (berat badan lahir $\geq 2.500$ gram) dapat menurunkan faktor risiko kejadian stunting sebesar 0,8 kali (OR=2,62, 95\% Cl:0,97-7,12). Hal ini berarti bahwa baduta pada rumah tangga rawan pangan memiliki risiko menderita stunting 2,62 kali lebih besar dibandingkan dengan baduta pada rumah tangga tahan pangan apabila baduta memiliki tinggi badan ibu normal dan tidak memiliki riwayat BBLR. Nilai $R^{2}(\%)=0,04$ berarti ketahanan pangan rumah tangga, tinggi badan ibu, dan riwayat berat badan lahir rendah secara bersama-sama dapat memprediksi kejadian stunting pada baduta usia 6-23 bulan sebesar $4 \%$, sedangkan sisanya $96 \%$ disebabkan oleh faktor lain.

Berdasarkan analisis pada Tabel 6, model yang dipilih adalah model 4 sebagai model yang

Tabel 6. Analisis regresi logistik variabel yang berhubungan dengan kejadian stunting pada baduta usia 6-23 bulan

\begin{tabular}{|c|c|c|c|c|}
\hline Variabel & $\begin{array}{c}\text { Model } 1 \\
\text { OR } \\
(95 \% \mathrm{Cl})\end{array}$ & $\begin{array}{c}\text { Model } 2 \\
\text { OR } \\
(95 \% \mathrm{Cl})\end{array}$ & $\begin{array}{c}\text { Model } 3 \\
\text { OR } \\
(95 \% \mathrm{Cl})\end{array}$ & $\begin{array}{c}\text { Model } 4 \\
\text { OR } \\
(95 \% \mathrm{Cl})\end{array}$ \\
\hline \multicolumn{5}{|c|}{ Ketahanan pangan rumah tangga } \\
\hline Rawan pangan & $2,70^{*}$ & 2,63 & 2,69 & 2,62 \\
\hline Tahan pangan & $(1,01-7,21)$ & $(0,98-7,09)$ & $(1,00-7,22)$ & $(0,97-7,12)$ \\
\hline \multicolumn{5}{|l|}{ Tinggi badan ibu } \\
\hline Pendek & & $2,01^{*}$ & & $1,96^{*}$ \\
\hline Normal & & $(1,16-3,48)$ & & $(1,12-3,41)$ \\
\hline \multicolumn{5}{|l|}{ Riwayat BBLR } \\
\hline BBLR & & & $3,01^{*}$ & 2,86 \\
\hline BBLN & & & $(1,04-8,68)$ & $(0,98-8,34)$ \\
\hline $\mathrm{R}^{2}$ & 0,01 & 0,03 & 0,02 & 0,04 \\
\hline $\mathrm{N}$ & 252 & 252 & 252 & 252 \\
\hline Deviance (-2 log likelihood) & 172,50 & 169,32 & 170,16 & 167,26 \\
\hline
\end{tabular}

* Signifikan $(p<0,05)$ 
cukup baik untuk menjelaskan hubungan ketahanan pangan rumah tangga dengan kejadian stunting pada baduta usia 6-23 bulan. Model 4 sudah mempertimbangkan semua variabel yang bermakna terhadap kejadian stunting, hasil $\mathrm{R}^{2}$ merupakan yang paling besar dan memiliki nilai deviance $(-2$ log likelihood) paling kecil.

Selanjutnya dilakukan analisis stratifikasi terhadap variabel yang diduga sebagai confounding dan atau efek modifier pada hubungan ketahanan pangan rumah tangga dengan kejadian stunting pada baduta usia 6-23 bulan. Variabel yang dianalisis adalah variabel yang memiliki hubungan yang signifikan $(p<0,05)$ pada analisis bivariat yaitu tinggi badan ibu dan riwayat BBLR baduta.

Hasil analisis yang diperoleh menunjukkan bahwa perbedaan crude OR dengan OR hasil uji Maentel Haenzel kedua variabel tersebut tidak lebih dari $20 \%$ yaitu $4,07 \%$ dan $0,74 \%$, sehingga dapat disimpulkan bahwa tinggi badan ibu dan riwayat BBLR baduta bukan variabel confounding bagi hubungan ketahanan pangan rumah tangga dengan kejadian stunting pada baduta usia 6-23 bulan. Namun demikian, analisis pada variabel tinggi badan ibu menunjukkan bahwa OR ketahanan pangan rumah tangga baduta yang memiliki tinggi badan ibu pendek berbeda dengan OR ketahanan pangan rumah tangga baduta yang memiliki tinggi badan ibu normal. Dengan demikian, dapat disimpulkan bahwa tinggi badan ibu merupakan effect modifier bagi hubungan ketahanan pangan rumah tangga dengan kejadian stunting pada baduta usia 6-23 bulan.

\section{BAHASAN}

\section{Hubungan ketahanan pangan rumah tangga dengan kejadian stunting pada baduta usia 6-23 bulan}

Hasil analisis menunjukkan bahwa rumah tangga dengan kategori rawan pangan lebih banyak terdapat pada kelompok kasus (baduta stunting) yakni $71,43 \%$ dibandingkan dengan kontrol (baduta yang memiliki panjang badan normal) yaitu $28,57 \%$. Hasil analisis menggunakan uji chi-square menunjukkan ketahanan pangan rumah tangga memiliki hubungan yang signifikan dengan kejadian stunting pada baduta usia 6-23 bulan ( $\mathrm{p}=0,04,95 \%$ Cl:1,04-7,00) (Tabel 2).

Analisis regresi logistik dengan mengikutsertakan variabel tinggi badan ibu dan riwayat BBLR baduta secara bersama-sama menunjukkan adanya hubungan yang signifikan antara ketahanan pangan rumah tangga dengan kejadian stunting pada baduta usia 6-23 bulan ( $p=0,05,95 \%$ Cl:0,97-7,12) (Tabel 6). Meskipun hasil analisis memiliki confidence interval yang melewati angka 1, namun berada pada posisi marginal dan secara keseluruhan lebih berat ke arah kanan atau bersifat positif, sehingga dapat disimpulkan pada kondisi ini hasil analisis dinyatakan berhubungan $(14,15)$.

Hasil penelitian ini juga membuktikan bahwa ketahanan pangan rumah tangga sebagai faktor risiko yang signifikan terhadap kejadian stunting pada baduta usia 6-23 bulan. Baduta pada rumah tangga rawan pangan memiliki risiko 2,62 kali lebih besar menderita stunting dibandingkan dengan baduta pada rumah tangga tahan pangan (Tabel 6). Secara klinis, tinggi badan ibu yang normal $(\geq 150$ $\mathrm{cm})$ dan riwayat berat badan lahir normal $(\geq 2.500 \mathrm{~g})$ dapat menurunkan risiko stunting pada baduta usia 6-23 bulan sebesar 0,8 kali dibandingkan dengan baduta yang memiliki tinggi badan ibu kurang $(<150$ $\mathrm{cm})$ dan riwayat baduta BBLR $(<2.500 \mathrm{~g})$. Hasil penelitian ini sejalan dengan penelitian di Nepal yang menjelaskan bahwa rumah tangga rawan pangan memiliki risiko yang lebih besar memiliki anak yang mengalami keterlambatan pertumbuhan dibandingkan dengan anak yang berasal dari rumah tangga tahan pangan (16).

Rumah tangga dengan kategori tahan pangan memiliki anggota keluarga yang mempunyai akses terhadap pangan, baik jumlah maupun mutunya dan hal ini akan berdampak pada terpenuhinya kebutuhan gizi baduta sehingga tercapai status gizi yang optimal (17). Baduta yang berada dalam kondisi rumah tangga tahan pangan memiliki tingkat kecukupan energi dan protein yang baik. Berbeda dengan baduta dari keluarga rawan pangan yang mengalami keterlambatan pertumbuhan karena kurang memiliki akses terhadap pangan, sehingga porsi makan dikurangi untuk berbagi dengan anggota keluarga lainnya (18-20). 
Menurut Ardiani dan Wiratmadji (21) baduta dikatakan memiliki akses kurang terhadap pangan jika kualitas dan kuantitas komposisi menu hariannya kurang lengkap serta frekuensi lauk nabati yang lebih dominan. Senada dengan hal ini, kerawanan pangan rumah tangga, komposisi menu yang tidak bergizi, tidak berimbang dan tidak bervariasi baik secara kualitas dan kuantitas dapat menyebabkan keterlambatan pertumbuhan dan kekurangan gizi pada balita (22).

Berdasarkan penjelasan tersebut, semakin tahan pangan suatu rumah tangga, maka semakin baik pula asupan makanan baduta. Hal ini disebabkan oleh akses rumah tangga terhadap pangan semakin baik sehingga kemampuan keluarga menyediakan makanan guna memenuhi kebutuhan gizi anak dan anggota keluarga semakin terpenuhi (23-25). Hasil analisis menunjukkan tidak ada hubungan antara ketahanan pangan rumah tangga dengan asupan energi dan protein baduta. Kejadian ini memberikan gambaran bahwa kerawanan pangan rumah tangga tidak selalu dapat menentukan asupan makan yang rendah. Rumah tangga rawan pangan mampu menyediakan makanan kepada baduta, sehingga asupan energi dan protein dapat terpenuhi sesuai kebutuhan seperti halnya pada baduta yang berasal dari rumah tangga tahan pangan.

Demikian pula dengan riwayat asupan energi dan protein tidak memiliki hubungan yang signifikan dengan kejadian stunting pada baduta usia 6-23 bulan. Data ini menunjukkan adanya distribusi yang setara antara kelompok rumah tangga rawan pangan dan kelompok rumah tangga tahan pangan dalam pemenuhan kebutuhan energi dan protein baduta usia 6-23 bulan. Membaiknya asupan zat gizi pada kelompok rumah tangga rawan pangan dimungkinkan oleh beberapa alasan: adanya program pemerintah yang berupaya membantu keterbatasan perekonomian keluarga kurang mampu melalui program bantuan langsung tunai (BLT), adanya program beras miskin (raskin) yang mampu menjangkau keluarga kurang mampu untuk membeli beras dengan harga murah, program pemerintah lainnya yang dapat meningkatkan kemampuan rumah tangga dalam memberikan asupan makan kepada baduta serta adanya bantuan sumber energi dan protein dari sumber lain misalnya tetangga. Berdasarkan hal ini, dapat dijelaskan bahwa pemenuhan kebutuhan makanan dalam rumah tangga guna memenuhi kebutuhan gizi baduta agar dapat tumbuh sesuai umurnya tidak hanya dilihat dari kemampuan keuangan keluarga, tetapi ada peran faktor lain berupa program pemerintah dalam menanggulangi kemiskinan.

Analisis stratifikasi menunjukkan tidak ada peran variabel confounding pada hubungan ketahanan pangan rumah tangga dengan kejadian stunting pada baduta usia 6-23 bulan (OR tidak lebih dari $20 \%$ ), namun dapat diketahui bahwa variabel tinggi badan ibu merupakan effect modifier pada hubungan ketahanan pangan rumah tangga dengan kejadian stunting pada baduta usia 6-23 bulan. Hal ini lah yang menjelaskan alasan rumah tangga rawan pangan memiliki baduta dengan ukuran panjang badan normal dan stunting (Tabel 7).

Tabel 7. Analisis stratifikasi variabel tinggi badan ibu dan riwayat BBLR baduta pada hubungan ketahanan pangan rumah tangga dengan kejadian stunting pada baduta usia 6-23 bulan

\begin{tabular}{|c|c|c|c|c|c|c|}
\hline Variabel & $\begin{array}{l}\text { Ketahanan pangan } \\
\text { rumah tangga }\end{array}$ & Kasus & Kontrol & OR & COR & $\begin{array}{l}\text { OR } \\
\text { MH }\end{array}$ \\
\hline \multicolumn{7}{|c|}{ Tinggi badan ibu } \\
\hline \multirow[t]{2}{*}{ Pendek } & Rawan pangan & 28 & 43 & 195 & \multirow{4}{*}{2,70} & \multirow{4}{*}{2,59} \\
\hline & Tahan pangan & 2 & 6 & 1,95 & & \\
\hline \multirow[t]{2}{*}{ Normal } & Rawan pangan & 92 & 68 & \multirow{2}{*}{3,04} & & \\
\hline & Tahan pangan & 4 & 9 & & & \\
\hline \multicolumn{7}{|c|}{ Riwayat BBLR baduta } \\
\hline \multirow[t]{2}{*}{ BBLR } & Rawan pangan & 5 & 12 & \multirow{2}{*}{$\sim$} & \multirow{4}{*}{2,70} & \multirow{4}{*}{2,72} \\
\hline & Tahan pangan & 0 & 2 & & & \\
\hline \multirow[t]{2}{*}{ BBLN } & Rawan pangan & 115 & 99 & \multirow{2}{*}{2,51} & & \\
\hline & Tahan pangan & 6 & 13 & & & \\
\hline
\end{tabular}




\section{Hubungan karakteristik, sosial ekonomi, dan status gizi orang tua dengan kejadian stunting pada baduta usia 6-23 bulan}

Hasil analisis menunjukkan tinggi badan ibu memiliki hubungan yang signifikan dengan kejadian stunting pada baduta usia 6-23 bulan ( $\mathrm{OR}=2,03$, 95\% Cl:1,14-3,65) (Tabel 3). Ibu dengan tinggi badan $<150 \mathrm{~cm}$ berisiko 2,03 kali memiliki anak stunting dibandingkan dengan ibu yang tinggi badannya normal (TB $\geq 150 \mathrm{~cm}$ ). Tinggi badan merupakan salah satu bentuk ekspresi genetik dan faktor yang diturunkan kepada anak, sehingga kejadian stunting juga merupakan cerminan tinggi badan ibu (26).

Riwayat BBLR baduta memiliki hubungan yang signifikan dengan kejadian stunting ( $O R=3,02,95 \%$ Cl:1,09-8,32) (Tabel 3). Bayi dengan berat badan lahir rendah mengalami retardasi pertumbuhan dalam uterus baik akut maupun kronis, sehingga jika bayi telah mengalami kekurangan gizi sejak awal kehamilan maka akan berdampak pada berat maupun panjang badan lahirnya kurus dan pendek (27).

Hasil penelitian ini menunjukkan tidak ada hubungan antara pendidikan ayah dan pendidikan ibu dengan kejadian stunting (Tabel 2). Penelitian ini sejalan dengan penelitian yang menyatakan pendidikan orang tua merupakan faktor risiko yang tidak signifikan terhadap kejadian stunting (28). Pendidikan orang tua yang tinggi akan memudahkan seseorang mengimplementasikan pengetahuannya dalam perilaku di bidang gizi dan kesehatan (29) dan memudahkan seseorang memperoleh pekerjaan yang lebih baik. Hasil penelitian menunjukkan pendidikan ayah dan pendidikan ibu pada kelompok kasus sebesar $65,87 \%$ dan $66,66 \%$ dalam kategori baik. Meskipun pendidikan orang tua baik, status bekerja orang tua menyebabkan alokasi waktu yang lebih sedikit untuk mengasuh, merawat, dan mendidik anakanaknya juga lebih sedikit serta kurang maksimalnya pembinaan dan pemeliharaan anak hingga berdampak pada gangguan pertumbuhan anak $(30,31)$.

Hasil analisis juga menunjukkan bahwa pengetahuan gizi ibu tidak berhubungan dengan kejadian stunting pada baduta (Tabel 3). Hal ini dapat disebabkan oleh waktu yang dialokasikan ibu untuk mengasuh anak sangat terbatas, karena ibu lebih banyak berada di luar rumah untuk bekerja mencari nafkah. Hasil penelitian menunjukkan sebanyak $84,13 \%$ ibu dari kelompok kasus bekerja membantu suami mencari nafkah. Pengetahuan dasar tentang gizi yang cukup tanpa diikuti sikap, keterampilan, dan kemauan untuk bertindak tidak akan dapat membawa perbaikan gizi balita (32).

Hasil analisis menunjukkan bahwa jenis kelamin baduta tidak berhubungan dengan kejadian stunting (Tabel 3). Anak perempuan dianggap sebagai anak yang lemah sehingga mendapatkan perhatian ekstra dibandingkan dengan anak laki-laki yang dianggap lebih kuat(33). Meskipun demikian, analisis ini memberikan gambaran perilaku orang tua yang merata dalam memberikan pola asuh kepada anaknya tanpa melihat jenis kelamin. Hal ini juga disebabkan oleh jumlah baduta dalam rumah tangga hanya satu orang, sehingga kasih sayang lebih diarahkan kepadanya karena melihat usia yang masih sangat bergantung kepada orang lain dibandingkan dengan saudaranya yang lebih tua.

Pekerjaan orang tua tidak berhubungan dengan kejadian stunting pada baduta (Tabel 2). Hal ini disebabkan oleh kurang maksimalnya pembinaan dan pemeliharaan anak sehingga menyebabkan gangguan pertumbuhan. Selain itu, orang tua memiliki interval waktu lebih banyak di luar untuk bekerja, sehingga tidak dapat mengontrol pola konsumsi makan anak dengan baik dan berimplikasi terhadap asuhan gizi yang tidak berimbang $(30,34)$. Orang tua yang bekerja dapat berdampak positif pada pertambahan pendapatan, sehingga akan memiliki kemampuan menyediakan makanan bagi anggota keluarga (35).

Pendapatan keluarga tidak berhubungan dengan kejadian stunting pada baduta (Tabel 2). Orang tua dengan pekerjaan yang baik memungkinkan mereka memiliki pendapatan yang lebih sehingga mampu memenuhi kebutuhan ekonomi, makanan, dan gizi anak agar terhindar dari stunting (33). Kemampuan ekonomi yang rendah berdampak pada ketidakmampuan untuk mendapatkan pangan yang cukup dan berkualitas karena rendahnya kemampuan daya beli (36). Hal ini disebabkan oleh membaiknya asupan makanan dari keluarga, meskipun keluarga 
tersebut berasal dari rumah tangga yang memiliki pendapatan rendah. Terjadinya hal ini dimungkinkan oleh adanya program pemerintah seperti BLT, raskin, dan program lain yang serupa, yang mampu meningkatkan keterjangkauan keluarga terhadap pangan sehingga kebutuhan gizi baduta dapat terpenuhi (37).

Jumlah anggota keluarga turut berperan terhadap ketersediaan pangan dalam rumah tangga (Tabel 3). Jumlah anak dan anggota keluarga yang besar akan mempengaruhi asupan makanan baduta dalam keluarga menjadi berkurang dan distribusi makanan menjadi tidak merata (16). Hasil penelitian ini menunjukkan bahwa tidak ada hubungan yang signifikan antara jumlah anggota keluarga dengan kejadian stunting pada baduta. Hal disebabkan oleh membaiknya asupan makanan baduta meskipun jumlah anggota keluarga lebih dari 4 orang. Membaiknya asupan makanan ini dimungkinkan oleh peran kedua orang tua yang bekerja mencari nafkah dan adanya program pemerintah seperi BLT, raskin dan program lain yang serupa, sehingga ketersediaan pangan dalam rumah tangga lebih terpenuhi (37).

Penyakit infeksi baduta memiliki hubungan yang tidak signifikan dengan kejadian stunting pada baduta (Tabel 3). Infeksi pada baduta berdampak pada malabsorbsi zat gizi, dehidrasi, dan kehilangan zat gizi. Bila kondisi ini tidak tertangani dengan baik akan terjadi gagal tumbuh. Tidak signifikannya hubungan ini bisa dijelaskan bahwa kejadian stunting menunjukkan adanya masalah gizi kronis yang berdampak pada pertumbuhan panjang badan yang tidak sesuai dengan pertumbuhan tinggi badan anak yang normal dalam rentang usia yang sama (38). Dalam penelitian ini, penyakit infeksi yang dianalisis adalah penyakit yang diderita dalam kurun waktu 2 minggu terakhir saat pengambilan data, sehingga tidak bisa menggambarkan kondisi kesehatan sejak awal proses terjadinya stunting. Penyebab lain adalah infeksi seperti batuk, pilek, dan demam yang menyertainya tergolong ringan dan akan sembuh dalam waktu singkat, sehingga tidak akan mempengaruhi proses pertumbuhan panjang badan. Di sisi lain dimungkinkan oleh nafsu makan anak tetap membaik meskipun menderita penyakit infeksi (34).

\section{KESIMPULAN DAN SARAN}

Berdasarkan hasil penelitian dapat disimpulkan bahwa rumah tangga rawan pangan sebagian besar terdapat pada kelompok kasus yaitu sebesar $71,43 \%$. Prevalensi baduta usia $6-23$ bulan stunting di Kecamatan Sedayu, Bantul, Yogyakarta adalah $16,17 \%$. Ada hubungan yang signifikan antara ketahanan pangan rumah tangga dengan kejadian stunting pada baduta usia 6-23 bulan di Kecamatan Sedayu, Bantul, Yogyakarta. Baduta dengan kondisi rumah tangga rawan pangan berisiko 2,62 kali lebih besar menderita stunting dibandingkan dengan baduta dengan kondisi rumah tangga tahan pangan.

Berdasarkan hasil penelitian ini disarankan agar Pemerintah Kabupaten Bantul dapat meningkatkan akses dan keterjangkauan masyarakat akan harga pangan dengan melakukan kegiatan pasar murah secara berkala. Pengelola Dinas Kesehatan Kabupaten Bantul dan Badan Ketahanan Pangan Kabupaten Bantul hendaknya melakukan penyuluhan mengenai MP-ASI berbasis pangan lokal. Bagi peneliti berikutnya yang ingin mengkaji faktor ketahanan pangan perlu mengikutsertakan program penanggulangan kemiskinan pemerintah dan program lain yang serupa dalam melakukan analisis.

\section{RUJUKAN}

1. Husaini M. Karakteristik sosial ekonomi rumah tangga dan tingkat ketahanan pangan rumah tangga petani di Kabupaten Barito Kuala. Agrides. 2012;4(2).

2. Damanik I. Strategi rumah tangga dalam memenuhi kebutuhan pangan (studi kasus: Desa Latuhalat Kecamatan Nusaniwe Kota Ambon). J Agroforestri. 2008;3(2).

3. Adriani M, Wirjatmadi B. Peranan gizi dalam siklus kehidupan. Jakarta: Kencana Prenada Media Group; 2012.

4. Sari M. Faktor-faktor yang mempengaruhi kerawanan pangan rumah tangga miskin di Desa Wiru Kecamatan Bringin Kabupaten Semarang. Jejak. 2009;2(2).

5. Sianipar J, Hartono S, Hutapea R. Analisis ketahanan pangan rumah tangga tani di Kabupaten Manokwari. Sepa. 2012;2(8):51-182. 
6. Kementerian Kesehatan R. Profil data kesehatan Indonesia tahun 2011. Jakarta: Kementerian Kesehatan RI; 2012.

7. Dinas Kesehatan Kabupaten Bantul. Laporan tahunan tahun 2012 Dinas Kesehatan Kabupaten Bantul. Bantul: Dinas Kesehatan Kabupaten Bantul; 2012.

8. Ulfani, Martianto, Baliwati. Faktor-faktor sosial ekonomi dan kesehatan masyarakat kaitannya dengan masalah gizi underweight, stunted, dan wasted di Indonesia: pendekatan ekologi gizi. JGIZIPANGAN. 2011;1(6):59-65.

9. Warnida Y. Hubungan ketahanan pangan tingkat rumah tangga dengan status gizi anak balita di Kecamatan Gondomanan D.I Yogyakarta. Universitas Gadjah Mada; 2007.

10. Falupi LA. Hubungan ketahanan pangan tingkat rumah tangga dengan status gizi anak batita usia 6-36 bulan di Kabupaten Purworejo. Universitas Gadjah Mada; 2009.

11. Lemeshow S, Hosmer DWJr, Klar J LS. Adequacy of sample size in health studies edisi Bahasa Indonesia. Yogyakarta: Universitas Gadjah Mada; 1997.

12. Radimer KL, Olson CM CC. Development of indicators to assess hunger. J Nutr Community Int Nutr. 1997;120 suppl(:1544S-1548S).

13. Prasetyo B, Jannah LM. Metode penelitian kuantitatif. Jakarta: PT Raja Grafindo Persada; 2010.

14. Murti B. Penerapan metode statistik nonparametrik dalam ilmu-ilmu kesehatan. Jakarta: PT Gramedia Pustaka Utama; 1996.

15. Sastroasmoro S, Ismael S. Dasar-dasar metodologi penelitian klinis. Jakarta: Sagung Seto; 2011.

16. Hellen Keller Internasional. Household food insecurity is highly prevalent and predicts stunting among preschool children and anemia among their mothers in Baitadi District of Nepal. Nepal: Nepal Nutrition and Food; 2010.

17. UNICEF. Tracking progress child and maternal nutrition a survival and development priority. New York: UNICEF; 2009.

18. Hayati AW, Hardinsyah, Jalal F, Madanijah S BD. Pola konsumsi pangan dan asupan energi dan zat gizi anak stunting dan tidak stunting 0-23 bulan. JGIZIPANGAN. 2012;2(7).

19. Anderson VP, Jack S, Monchy D, Hem N, Hok P, Bailey KB, Gibson SB. Co-existing micronutrient deficiencies among stunted cambodian infants and toddlers. Asia Pacific $J$ Clin Nutr. 2008;17(1):72-9.

20. Ajao KO, Ojofeitimi EO, Adebayo AA., Fatusi AO, Afolabi OT. Influence of family size, household food security status, and child care practices on the nutritional status of under-five children in ile-ife, Nigeria. Afr J Reprod Health. 2010;14(4): 123-32.

21. Adriani M, Wirjatmadi B. Pengantar gizi masyarakat. Jakarta: Kencana Prenada Media Group; 2012.

22. Tessema, Belachew, Ersino. Feeding patterns and stunting during early childhood in rural communities of Sidama South Ethiopia. Pan Afr Med J. 2013;14: 1-12.

23. Natalia LD, Rahayuning D FS. Hubungan ketahanan pangan tingkat keluarga dan tingkat kecukupan zat gizi dengan status gizi batita di Desa Gondangwinangun. J Kesehat Masy. 2012;2(2).

24. Rohaedi S. Hubungan antara tingkat ketahanan pangan rumah tangga dengan status gizi balita pada rumah tangga di daerah rawan pangan Kabupaten Indramayu. J Gizi dan Diet Indones. 2014; 2(2):85-92.

25. Martianto D, Riyadi H AR. Pola asuh makan pada rumah tangga yang tahan dan tidak tahan pangan serta kaitannya dengan status gizi anak balita di Kabupaten Banjarnegara. JGIZIPANGAN. 2011;6(1):51-8.

26. Supariasa IN, Bakri F. Penilaian status gizi. Jakarta: EGC; 2010.

27. Kusharisupeni. Growth faltering pada bayi di Kabupaten Indramayu Jawa Barat. Makara Kesehat. 2002;(6):1-5.

28. Kusuma KE N. Faktor risiko kejadian stunting pada anak usia 2-3 tahun (studi di Kecamatan Semarang Timur). J Nutr Coll. 2013;(2):523-30.

29. Atmarita FT. Analisis Situasi Gizi dan Kesehatan Masyarakat. Jakarta: Widya Karya Nasional Pangan dan Gizi VIII, LIPI; 2004. 
30. Susilaningdyah A. Pola asuh sebagai faktor risiko kejadian stunting pada anak usia 6-24 bulan di Kota Yogyakarta. Universitas Gadjah Mada; 2013.

31. Tanziha I, Kusriadi. Faktor-faktor yang mempengaruhi kejadian stunting pada balita di Kabupaten Lombok Tengah Provinsi Nusa Tenggara Barat. J IIm Agropolitan. 2010;3(2).

32. Soekirman. IImu Gizi dan Aplikasinya Untuk Keluarga dan Masyarakat. Jakarta: Direktorat Jenderal Pendidikan Tinggi. Departemen Pendidikan Nasional; 2000.

33. Rosha BCh, Hardinsyah BY. Analisis determinan stunting anak 0-23 bulan Pada daerah miskin di Jawa Tengah dan Jawa Timur. J Penelit Gizi dan Makanan. 2012;(35):34-4.

34. Astari LD, Nasution A DC. Hubungan konsumsi ASI dan MP-ASI serta kejadian stunting anak usia 6-12 bulan di Kabupaten Bogor. J Media Gizi dan Kel. 2012;30(1):15-23.

35. Linda O HD. Hubungan pendidikan dan pekerjaan orang tua serta pola asuh dengan status gizi balita di Kota dan Kabupaten Tanggerang Banten. Proseding Penelitian Bidang IImu dan Eksakta; 2011.

36. Anugraheni HS, Kartasurya I. Faktor risiko kejadian stunting pada anak usia 12-36 bulan di Kecamatan Pati Kabupaten Pati. J Nutr Coll. 2012;1(1):30-7.

37. Aries M, Hardinsyah TH. Determinan gizi kurang anak umur 0-36 bulan berdasarkan data program keluarga harapan (PKH) 2007. JGIZIPANGAN. 2012;7(1):19-26.

38. Departemen Gizi dan Kesehatan Masyarakat FKM-UI. Gizi dan kesehatan masyarakat. Jakarta: PT Raja Grafindo Persada; 2012. 